\title{
The Role of Sustainable Communication on Human Behavior on Recycling: A Case of Turkey
}

\author{
Zekiye Tamer Gencer (Assoc. Prof. Dr.) \\ Cumhuriyet University Faculty of Communication \\ zgencer@cumhuriyet.edu.tr \\ Date Received: 10.03.2021 \\ Date Accepted: 24.05.2021 \\ Date Published: 30.07.2021 \\ https://doi.org/10.17680/erciyesiletisim.894468
}

\section{Abstract}

The resources that nature offers to human beings are of course not infinite, unless there is a conscious and careful use, an "end" is coming in terms of natural resources. Preventing waste of resources, protecting nature and gaining the habit of recycling are now inevitable in order for healthy generations to continue their lives and to increase their economic development levels. There are not enough studies in the literature on the subject. The current study aims to determine the levels of individuals' behaviors and attitudes regarding the subject. The literature review section is divided into two sections. The first section briefly explains the recycling issue. The second section includes studies on recycling in Turkey and in the world. The current study measured and determined the focus group's level of awareness about recycling. SPSS was used to analyze the data. A total of 4885 people participated in the study. $60.8 \%$ of the participants were women and $39.2 \%$ of them were men. Participants had an average score of 106.04 (SD = 17.80) from the environmental awareness and sensitivity scale and considering that the maximum score to be obtained was 140 , the participants were at a partially good level in terms of environmental awareness and sensitivity.

Keywords: Environmental Awareness, Recycling, Household Waste, Trends of Consumer. 


\title{
Geri Dönüşüm Konusunda Sürdürülebilir Illetişimin İnsan Davranışı Üzerindeki Rolü: Türkiye Örneği
}

\author{
Zekiye Tamer Gencer (Doç. Dr.) \\ Cumhuriyet Üniversitesi Iletişim Fakültesi \\ zgencer@cumhuriyet.edu.tr \\ Başvuru Tarihi: 10.03.2021 \\ Yayına Kabul Tarihi: 24.05.2021 \\ Yayınlanma Tarihi: 30.07 .2021 \\ https://doi.org/10.17680/erciyesiletisim. 894468 \\ Öz
}

Doğanın insanoğluna sunduğu kaynaklar elbette ki sonsuz değildir, bilinçli ve dikkatli kullanım olmadığı sürece doğal kaynaklar açısından da bir "son" mümkündür. Hem sağlıklı nesillerin yaşamaya devam etmesi hem de ekonomik kalkınmışlık düzeylerinin artırılması için kaynak israfını önlemek, doğayı korumak ve geri dönüşüm alışkanlığı kazanmak günümüz insanı için artık kaçınılmazdır. Dünya ülkelerinin de bu durum hakkında farkındalık düzeyinin artmasıyla ve doğayı korumak kaygısı ile atıkların yeniden kullanıma kazandırılması noktasında birçok farklı yöntem arayışı devam etmektedir. Bunun için de ihtiyaç duyulan şey yerel çözümler üretmek ve insanların konu hakkında bilinçlenerek davranışlarının değiştirilmesini teşvik etmektir. Konuya ilişkin literatürde yeterince çalışma bulunmamaktadır. $\mathrm{Bu}$ çalışmada geri dönüşüm konusunda Türkiye ve Dünyada yapılan çalışmaların ve temel kavramsal tanımlar ile güncel istatistiki verilerin yer aldığı literatür kısmı ile geri dönüşüm konusu açıklanmıştır. Seçilen hedef kitle üzerinde, geri dönüşüm konusundaki bilinç düzeyini ölçme ve tespit etme amacıyla bir araștırma yapılmıștır. Elde edilen veriler SPSS programı ile analiz edilmiştir. Çalışmaya toplam 4885 kişi katılmıștır. Katılımcıların \%60,8 i kadın, \%39,2 si erkektir. Katılımcıların çevre bilinci ve duyarlılığı ölçeğinden aldıkları ortalama puan ise; 106,04 (st.sapma=17,80) şeklindedir ve buradan alınacak maksimum puanın 140 olduğu düşünüldüğünde, katılımcıların çevre bilinci ve duyarlılığı noktasında kısmen iyi bir düzeyde oldukları tespit edilmiştir.

Anahtar Kelimeler: Çevre Bilinci, Geri Dönüşüm, Ev Tipi Atık, Tüketici Eğilimleri. 


\section{Introduction}

The waste of resources, which is caused by many factors, especially by the developing technology and changing living conditions, made the concept of "recycling" more important than ever. The recycling mechanism, which aims to prevent the reduction of the world's natural resources, excessive waste of resources and the damage to nature by man, has now become a process that all humanity thinks over. The excessive waste of resources, which has become an issue not only in Turkey but also in all countries of the world, requires various measurements. The rapid changes in the consumption culture along with the developments in technology have led people to think daily and move away from the fact that the world's resources will run out at the end of the next century. In addition, the fact that people produce more than they can consume, that is, the imbalance between supply and demand, is one of the indicators of resource waste.

People living in technology-based industrial societies in the modern world face extremely harsh biophysical boundaries and the negative consequences of disrupting natural ecosystems. This reality certainly creates a new behavioral context, which drives the citizens of societies to seek new resources and develop new ways to use those resources, to protect nature while being conscious of finite ecosystems, to prevent waste and to implement recycling practices. This transition, which is an insurance for the future of the world, is inevitable. This reality and the required social change process necessitate a serious behavioral change in terms of people's psychological capacities (e.g. social, emotional, cognitive). Therefore, emotional stability and determination should be the priority. New interventions, which are formed with a number of changes that need to be made in how pro-environmental behaviors are encouraged, should create the conditions for people to be behavioral entrepreneurs and should be encouraging by ensuring the spread of this behavior.

It is very important that human behavior regarding this sensitive issue changes in the desired direction. Changes in behavior that are possible to change thanks to sustainable communication will build positive results. Therefore, it is possible to change behaviors and attitudes through sustainable communication and persuasion.

This study, which raises awareness about all the garbage and waste that people throw into the environment, especially household food waste, aims to raise awareness on important issues such as protecting the nature and preventing waste when these wastes are recovered through recycling, and to make suggestions on awareness raising and orientation work that will enable them to change their behaviors and attitudes. Sustainable natural resources and their protection are not possible without protective human behavior patterns. The needs for human sensitivity and communication are increasing day by day to prevent waste of resources and to spread the idea of recycling. The negativities experienced in environmental problems and the rapid consumption of the world's resources require conservation behavior and a change of behavior in this sense because in the world we live in, the need for all people to hear better stories about the future is increasing day by day.

Many studies draw attention to the importance of the behaviors of women who assume an important responsibility in recycling household waste. It is a possibility fact that the storage volume of recyclable wastes decreases by substantially when full separation is made in household wastes. Used oils, kitchen type glass, plastic, tin, and especially vegetable, fruit, egg waste and waste parts of meat are all in the category of household 
waste. Most of the household waste consists of recyclable waste. Raising awareness and consciousness about household type recyclable wastes makes raising environmentally sensitive individuals possible for women who raise future generations. Furthermore, the awareness created by the agenda which is created with the power of sustainable communication drives local governments to take actions on waste and recycling.

\section{Studies Conducted in Turkey and in The World}

All studies and all measures taken on the issue of recycling and protection of resources, which occupy the agenda both in Turkey and in many countries of the world, can only produce positive results at the desired level with human participation. Therefore, both traditional mass media and social media tools, which have an important role in agenda management, should be used effectively. Public awareness and mobilization of masses are only possible through media messages. There is a vast amount of literature on this subject both in Turkey and in the world. Therefore, the following section of this study includes these studies.

\section{Studies Conducted in Turkey}

A growing body of literature in Turkey has examined the subject, yet, preventing food waste caused by domestic consumption and ensuring behavioral changes of people through communication, which are the main limitations of the current study, have been core problems of other studies as well.

Despite this interest, no one in Turkey, to the best of the researcher's knowledge, has examined the direct relationship between social media and recycling/environmental awareness. In addition, focus groups of studies on social media are mostly university students (Harman \& Çelikler, 2016; Taş Divrik, Karakaş, \& Divrik, 2018; Tunç, Ömür, \& Düren, 2012; Vural \& Bat, 2010; Yllmaz \& Doğan, 2016).These studies have examined university students' purposes of using social media (Vural \& Bat, 2010), their recycling behaviors (Yılmaz \& Doğan, 2016), their attitudes towards recycling (Taş Divrik vd., 2018) and their recycling or environmental awarenesses (Dinç \& Üztemur, 2016; Harman \& Çelikler, 2016; Tunç vd., 2012). Another study has examined the effect of education given by using creative drama method on preschool students' environmental awarenesses (Aydın \& Aykaç, 2016).Another study that has examined the environmental awareness of primary school students has focused on the relationship between this awareness and course curricula(Gönüllü, Doğan, \& Çelik, 2015). However, there has been no discussion on social media or women regarding studies on recycling or environmental awareness. (Fidan \& Acar Şentürk, 2016) have examined how women use Facebook, a social media platform, in their daily communication processes in their study called "An Evaluation about communications and Women at Social Media".

Karaca (2013) conducted a study in Sivas, Turkey with 362 participants. The results concluded that $47.5 \%$ of the participants strongly agreed with "Buying products made of recycled paper helps protecting our forests" statement while $41.4 \%$ of the participants strongly agreed with "I can understand whether products are environmentally friendly from the signs and symbols on them" statement. The fact that $40.3 \%$ of the participants agreed with "I can understand whether they are environmentally friendly or not from the information about the content of many products" statement revealed that they are conscious consumers. $38.7 \%$ of the participants agreed with "I like putting the thing to be thrown away to use and producing or creating other things using them" statement. 
Yllmaz \& Doğan (2016) carried out a study using the structural equation modeling. Their study stated that recycling was one of the most important environmental behaviors that allow the conservation of resources and the reduction of solid waste, and underlined that investigating the factors that lead individuals to recycling behavior for a sustainable world is important. Their results determined that the proposed model can be used to explain recycling behaviors. Furthermore, they stated that people whose opinions were valued had positive effects in guiding others' recycling behaviors (Yllmaz \& Doğan, 2016, p. 191)

Hobikoğlu (2013) stated that the recycling of electronic wastes was important both economically and in terms of environment and living health, and concluded that the inclusion of the e-waste stock in the recycling process, which emerged with the rapid growth of the information and communication sector, depended on the approach of the household. The study showed that there was a big gap in the Istanbul region regarding waste and this gap could be directed to recycling facilities with the right guidance. She argued that while the efficient operation of the facilities to be established prevented waste of resources, the perception of investing in this area would ensure that the risk rate was low. She discussed that the use of recycling facilities would be shaped by the participation preference of households (Hobikoğlu, 2013, p. 55)

Hayta (2009) drew attention to the importance of education of consumers. Her study included consumer education, educational programs and tools prepared for each individual in the society to become a conscious consumer, even a citizen. Consumer education is defined as an education and information investment that aims to direct the economic activities of individuals, meet their needs, use their resources rationally, learn their fundamental rights, and increase their power to influence the market. Consumer education helps consumers to gain maximum benefit from consumption, increase their decision-making capacities, understand the economy and changing market conditions by improving their values and capabilities. Each consumer has a different consumption behavior than the other and learns new behaviors every day. Changing negative behaviors and perspective is only possible with education. With education, consumers can identify their priorities and adopt realistic and planned purchasing behavior, thus they can save money, time and energy. By paying attention to the labels of the products and the substances they contain, consumers may prefer products that are made of or packaged with materials that do not harm nature, do not create excess and harmful waste and can be reused. They can also reduce household waste. For example, empty glass, plastic and paper packaging can be reused by storing them or by collecting them separately from other wastes (Hayta, 2009).

Çabuk, Nakıboğlu, \& Keleş (2008) examined the relationships between the sociodemographic characteristics of consumers and their green purchasing behaviors. They conducted the field study with a survey with 600 consumers in Adana's largest shopping center. The results of the study indicated that there were significant relationships between consumers' green purchasing behaviors and their genders, marital statuses, ages, education and income levels. Consumers who bought green products were women, married, young, educated, and individuals with high household income (Çabuk vd., 2008, p. 85)

Öztekin, Teksöz, Pamuk, Sahin, \& Kilic (2017) evaluated the role of some sociopsychological characteristics in explaining the recycling behavior of the Turkish university 
community from a gender perspective in the context of planned behavior theory with a co-variable (past experiences). The study examined the recycling behavior of the whole sample in three sessions based on discussions, which explain the gendered private and public environmental behavior pattern and adhering to the fact that why women do not have stronger environmental values, beliefs and attitudes. The result of model runs indicated different variables that shaped behavioral intention, namely perceived behavior controls for women and past behaviors for men. Women were identified as those who did not fulfill their intentions (non-recyclers) due to the low variance in explaining their recycling behaviors. While women's attitudes were innate (recycling is good, necessary, useful and sensitive), men's attitudes were learned (recycling is healthy, valuable and correct). Therefore, the study observed that the recycling intention of men was shaped by past behaviors and the results were supported by men who had learned the recycling intention while the lack of intention of women was shaped by their perceived behavior control and their innate attitudes to recycling were important.

\section{Studies Conducted in the World}

Many studies have been published on the subject: however, few studies have examined the effect of the human factor on the recycling process. The following section of the current paper includes them.

Gosling \& Williams (2010) conducted a study which investigated the relationship between pro-environmental behavior and two emotional association forms: local attachment and attachment to nature. They investigated this relationship in the context of people's management of local vegetation on their properties. They conducted a postal survey with 141 people in northwest Australia to measure how connected people felt to nature and their properties. Their results indicated that vegetation protection behaviors increased with connectedness to nature (CNS), although CNS led to only a modest amount of the variation in behavior. The findings focused on studies showing the relationship between CNS and simpler conservation behaviors (e.g. recycling). The findings are consistent with frameworks that show that the emotional relationship with nature leads to an expanded sense of self and greater valuation of non-human species and thus pro-environmental behavior. Therefore, the study showed the importance of using various instrumental and more effective strategies to promote conservation behaviors (Gosling \& Williams, 2010, p. 298).

De Young (2019) has carried out numerous applied studies on the subject. One of his studies focused on the satisfaction obtained from recycling household solid waste materials. Data from 107 participants who participated in the feedback questionnaire were subjected to dimensional analysis and variance analysis. The results showed that people achieved a number of separate and distinct satisfactions from both recycling and reuse materials. Findings were highly specific, such as thrift and participation. Furthermore, he argued that our understanding of why people strove to conserve resources could be improved by exploring personal satisfactions resulting from conservation activities (De Young, 1986, p. 435). Another one of his studies drew attention to the education of people on the subject. He briefly mentioned the need for new methods. He underlined that technoindustrial societies faced biophysical limits and the consequences of destroying Earth's ecosystems. According to him, this would end up creating a new behavioral context with a firm demand. This demand underlined that citizens of such societies should shift their focus from searching for new resources and should instead focus on creating new life patterns that work well in finite ecosystems. He argued that this was a certain shift, 
however, people could not predict the necessary pro-environmental behavior since this was a complex shift that would take decades to implement. Furthermore, he discussed that incremental and serial changes would not be enough since the obligation to respond would require the adoption of all sets of behaviors. In this regard, he suggested that societies should implement a culture of small experiments. He underlined that the process of change required serious social, emotional and attention capacities. Furthermore, he suggested that societies should implement changes in how environmentally friendly behaviors were encouraged. He suggested that people "move beyond interventions that are expert-driven, modest in request, serial in implementation and short-term in horizon. New interventions must create the conditions under which citizens become behavioral entrepreneurs, themselves creating, managing and sharing successful approaches to behavior change." (De Young, 2019, p. 295)

Ebreo \& Vining (1994) examined the relationship between environmentally conscious consumerism and self-reported recycling behavior, and the impact of experience in solid waste management and the impact of the sociopolitical environment surrounding waste management on consumers' beliefs. They studied with 654 randomly selected adults living in rural and urban areas in central Illinois using a mail survey. The study examined the individuals' participation in recycling programs and their reactions to properties of consumer products that were believed leading consumers to positive environmental outcomes. Participants evaluated the importance of fourteen product properties, these were later associated with recycling behaviors reported by the participants. The results showed the contribution of participants' behaviors to environmental consequences. The results indicated that recycling behaviors and environmentally friendly consumption were weakly interrelated and linked to the individuals' views of the conservation of natural resources. Contrary to their expectations, the participants' responses did not differ significantly regarding rural and urban residents, pointing out that recycling and the solid waste management policy experiences of these participants did not affect their reactions (Ebreo \& Vining, 1994).

Another study conducted by Granzin \& Olsen, (1991) aimed to give ideas to policy makers and practitioners. They divided participants into three relevant but different environmental protection activities. They examined reuse, newspaper recycling and preservation. Their findings showed that participants' demographic characteristics, media usage habits, information sources and knowledge provide a moderate understanding of their environmental protection activities. They suggested that the findings may help policy makers to implement some ideas about how environmental protection activities could be encouraged in the best way (Granzin \& Olsen, 1991, p. 1)

Corral-Verdugo (1997) studied with 100 randomly selected Mexican housewives. The study both directly observed the frequency of reused/recycled items in these families and enabled women to report their own attitudes. The study compared self-reported and observed measurements, and the findings indicated low correlations between self-reports and observations on reuse/recycling. In addition, he used a different model in which reports and observations were by a number of factors (beliefs, motives, competencies) verbally and non-verbally. The results revealed that the verbally assessed beliefs were only related to the self-reported evaluations while the non-verbal evaluated competencies were related to the observed behaviors. On the other hand, motives (assessed verbally or nonverbally) were related to both self-reported and observed reuse and recycling. He then stated that "these results indicate that competencies are more indicative of instrumental 
(observed) behavior, while beliefs are more related to a 'reality' of social conventions and desires, which directs verbal self-reports" ( s. 135)

Jekria \& Daud (2016) aimed to determine the recycling behavior of 143 households in Selangor. Analyzing the data using the Structural Equation Modeling, they concluded that environmental concerns were important to participants' attitudes and those attitudes helped them increase their environmental concerns to promote their recycling behavior. They argued that the study helped understanding the attitudes towards recycling among households (Jekria \& Daud, 2016, p. 667)

Latif, Omar, Bidin, \& Awang (2012) examined the causal relationships between environmental values and recycling behaviors of 300 participants living in two urban areas using a survey. They used structural equation modeling to obtain measurement models and structural models. Their results indicated differences in participants' recycling behaviors of two samples. They found environmental value as an important determinant of recycling behavior in both urban areas, however, it had a greater impact in Kuala Lumpur compared to Kota Kinabalu. They suggested that their study might help local governments overcome the urban waste management (Latif vd., 2012, p. 989)

Singhirunnusorn, Donlakorn, \& Kaewhanin (2012) examined the factors that influenced household recycling behavior and the possibility of household participation in a community-based recycling bank project. Their study investigated two communities in Mahasarakham, where there were differences in conditions and waste recycling management. Their results indicated that participants' demographic characteristics and socio-economic factors played a minor role in waste separation and recycling behavior at household level. Furthermore, their study determined that participants' environmental knowledge levels and attitudes contributed to people's perceptions, awareness and participation in the community-based recycling project (Singhirunnusorn vd., 2012, p. 688)

Akil, Foziah, \& Ho (2015) conducted a study with 600 households using a survey in Malaysia and examined the effect of socio-economic factors that might have effects on recycling practices. The results indicated that socio-economic factors had a positive relationship in recycling activities. Furthermore, they stated that elderlies had proenvironmental behaviors while the younger generation was less interested in recycling (Akil vd., 2015, p.124)

\section{Method}

This current study aims to measure a level of consciousness towards household consumption and general environmental awareness towards recycling and conservation of resources. The researcher carried out a survey to determine the participants' levels of environmental awareness and their tendencies to use environmentally friendly products in the case of Turkey. The study used a scale, which was developed to measure a similar purpose in a study conducted by Karaca in 2013, in the questionnaire form. In this study the hypotheses are as follows;

H1. Whether there is a relationship with environmental awareness scores of the participants and their demographic status (T TEST)

H1a. Whether there is a relationship with environmental awareness scores of the participants and their gender (T TEST) 
H1b. Whether there is a relationship with environmental awareness scores of the participants and their marital status (T TEST)

H1c. Whether there is a relationship with environmental awareness scores of the participants and their family type (T TEST)

H2. Whether there is a relationship with environmental awareness scores of the participants and their bought an environmentally friendly product so far (T TEST)

H3. Whether there is a relationship with environmental awareness scores of the participants and their considered if a product is environmentally friendly when buying it (T TEST)

H4. Whether there is a relationship with environmental awareness scores of the participants and their interests in plants when you were a child (T TEST)

H5. Whether there is a relationship with environmental awareness scores of the participants and their take care of an animal (T TEST)

H6. Whether there is a relationship with environmental awareness scores of the participants and their communications for environmental issues (T TEST)

In addition, the questionnaire form included questions to obtain data about demographic characteristics of the participants such as their ages, their education levels, their occupations, their social media usage habits and their recycling behaviors. The questionnaire form was applied to the group selected by simple random sampling method. The study preferred the survey method over a qualitative method because the population was large and the study used measured attitudes. After reviewing the relevant literature, the most frequently used scale was determined and data were obtained using this scale after the demographic questions in the questionnaire form. The study used a convenience sampling method, and participants were at least 18 years old. The data were collected electronically (google forma) by survey method at 2021 between January and February. After collecting the data from the sample, the study used SPSS to measure participants' levels of consciousness and their behaviors about recycling. In this study research questions are also research limitations. The research questions determined for this study are as follows.

Do the participants' levels of awareness on recycling and nature conservation vary according to their demographic characteristics?

What are the participants' levels of knowledge on household recycling in terms of food consumption?

What are the participants' levels of household recycling awareness?

What are the participants' levels of follow-up of media and press contents related to recycling and nature protection?

What are the participants' levels of information and content production from their personal media and social media accounts on recycling?

\section{Ethics Committee Permission}

Within the framework of the decision taken during the meeting by Social and Human Sciences Ethics Committee of Cumhuriyet University dated 21.01.2021 and numbered 37; the study does not contain any ethical issues. 


\section{Findings}

The reliability level (Cronbach's alpha $=0.863$ ) of the questionnaire form used for the research was at the level of $86 \%$. This ensured the validity and reliability of the questionnaire. The questionnaire form reached 4957 people, but 4885 of them were compiled as usable. The sub-dimensions of the scales developed by Karaca (2013)are environmentalism factor, economics factor, consciousness factor, responsibility factor, sensitivity factor and media factor. This study calculated an overall score for the scale and made all comparisons based on this awareness score. The average age of the participants was $31.59(\mathrm{SD}=11.57)$ and the age range was between 18 and 65 . The average income of the participants, which is an important criterion in recycling behavior, was TL 2536.78 (SD $=1668.75$ ). The average score that the participants got from the scale of environmental awareness and sensitivity was 106.04 (SD = 17.80), and considering that the maximum score to be obtained here was 140 , the study determined that the participants were at a good level of environmental awareness and sensitivity. Other analyzes and findings are listed in the following pages in table forms.

The study examined the demographic characteristics of the participants using frequency analysis. $60.8 \%$ of the participants were women, $39.2 \%$ of them were men, and $48.3 \%$ of them were married and $51.7 \%$ of them were single. $60.8 \%$ of the participants were women, $39.2 \%$ of them were men, and $48.3 \%$ of them were married and $51.7 \%$ of them were single. $22.7 \%$ of the participants were primary and secondary school graduates, $36.4 \%$ of them were high school graduates and $40.9 \%$ of them were university graduates. $38.6 \%$ of the participants stated that their income was less than their expenses, $46.5 \%$ of them stated that their income was equal to their expenses and $14.9 \%$ of them stated that their income was more than their expenses. The distribution of the place where participants lived the most, which is an important factor in the formation of environmental awareness, is as follows. $23.1 \%$ of the participants lived in metropolitans, $36.6 \%$ of them lived in cities and $40.3 \%$ of them lived in districts, villages or towns. The distribution of the place where participants lived during the survey period is as follows. $20.8 \%$ of the participants lived in metropolitans, $46.3 \%$ of them lived in cities and $32.8 \%$ of them lived in districts, villages or towns. In addition, the distribution of participants' family types, which is considered as an important variable in planning household recycling, is as follows. $75.8 \%$ of the participants lived with nuclear families and $24.2 \%$ of them lived with extended families. The distribution of ways of utilizing kitchen waste, the amount of which varies according to the family type, is as follows. $48.4 \%$ of the participants stated that they usually would give kitchen waste to stray animals. However, a large proportion of $31.5 \%$ of the participants stated that they would throw it away.

The results indicated that most of the participants (56.6\%) were online for four hour or more per week. Their purposes of using the internet were mostly (43.1\%) games and entertainment contents.

The study compared the participants' periods as when they were children and adults since the participants were over 18 years old. While the rate of those who had been interested in plants when they were children was $75.2 \%$, the rate of those who were interested during the survey period dropped to $57.4 \%$. Likewise, those who had been taking care of animals as children were $75.1 \%$, the rate dropped to $54.2 \%$ when they became adults. 
Table 1. Environmental awareness levels of the participants

\begin{tabular}{|c|c|c|c|}
\hline Tables & Groups & Frequencies(n) & Percentages (\%) \\
\hline \multirow{3}{*}{$\begin{array}{l}\text { Have you bought an } \\
\text { environmentally friendly } \\
\text { product so far? }\end{array}$} & Yes & 3374 & 69,1 \\
\hline & No & 1511 & 30,9 \\
\hline & Total & 4885 & 100,0 \\
\hline \multirow{3}{*}{$\begin{array}{l}\text { Do you consider if a } \\
\text { product is environmentally } \\
\text { friendly when buying it? }\end{array}$} & Yes & 3401 & 69,6 \\
\hline & No & 1484 & 30,4 \\
\hline & Total & 4885 & 100,0 \\
\hline \multirow{3}{*}{$\begin{array}{l}\text { Do you talk to your } \\
\text { family members about } \\
\text { environmental issues? }\end{array}$} & Yes & 2952 & 60,4 \\
\hline & No & 1933 & 39,6 \\
\hline & Total & 4885 & 100,0 \\
\hline \multirow{3}{*}{$\begin{array}{l}\text { Do you talk to your friends } \\
\text { about environmental issues? }\end{array}$} & Yes & 3023 & 61,9 \\
\hline & No & 1862 & 38,1 \\
\hline & Total & 4885 & 100,0 \\
\hline \multirow{3}{*}{$\begin{array}{l}\text { Do you follow the media content } \\
\text { about environmental issues? }\end{array}$} & Yes & 2640 & 54,0 \\
\hline & No & 2245 & 46,0 \\
\hline & Total & 4885 & 100,0 \\
\hline \multirow{3}{*}{$\begin{array}{l}\text { Do you post about } \\
\text { environmental issues from your } \\
\text { own social media accounts? }\end{array}$} & Yes & 1936 & 39,6 \\
\hline & No & 2949 & 60,4 \\
\hline & Total & 4885 & 100,0 \\
\hline
\end{tabular}

The response levels of the participants regarding their environmental sensitivity indicated a positive attitude in general. Buying environmentally friendly products at least once (69.1\%), considering if a product is environmentally friendly while buying it (69.6\%), talking about environmental issues to their families (60.4\%) and to their friends (61.9\%) showed that they had awareness of the issue. In addition, the rate of following $(54.0 \%)$ related media content was also high. The most striking result emerged from the analysis was that although participants stated that they followed the related media content, their level of posting about the subject from their own social media accounts (39.6\%) was low. The fact that social media usage habits were generally in the form of games and entertainment could be considered among the reasons for this.

Table 2. Comparison between Environmental Awareness Scores of the

Participants and Their Demographic Characteristics (T-TEST)

\begin{tabular}{|l|c|c|}
\hline Demographic Characteristics & $\mathbf{n}$ & \multicolumn{1}{|c|}{$\begin{array}{c}\text { Environmental } \\
\text { Awareness Score }\end{array}$} \\
\hline Gender* & \multicolumn{2}{|l|}{} \\
\hline Female & 2792 & $107,5 \pm 16,9$ \\
\hline Male & 1913 & $103,7 \pm 18,8$ \\
\hline $\mathrm{t}=$ & 7,094 & \\
\hline $\mathrm{p}=$ & 0,000 & \\
\hline Marital Status & & \\
\hline Married & 2359 & $107,1 \pm 17,6$ \\
\hline Single & 2526 & $104,9 \pm 17,8$ \\
\hline $\mathrm{t}=$ & 0,345 & \\
\hline $\mathrm{p}=$ & 0,000 & \\
\hline
\end{tabular}




\begin{tabular}{|c|c|c|}
\hline Demographic Characteristics & $\mathbf{n}$ & $\begin{array}{c}\text { Environmental } \\
\text { Awareness Score }\end{array}$ \\
\hline \multicolumn{3}{|l|}{ Family type* } \\
\hline Nuclear family & 3701 & $106,7 \pm 17,3$ \\
\hline Extended family & 1184 & $103,9 \pm 19,1$ \\
\hline$t=$ & 4,429 & \\
\hline$p=$ & 0,000 & \\
\hline \multicolumn{3}{|c|}{ Have you ever bought an environmentally friendly product so far?* } \\
\hline Yes & 3374 & $108,0 \pm 17,1$ \\
\hline No & 1511 & $101,6 \pm 18,3$ \\
\hline$t=$ & 11,810 & \\
\hline $\mathrm{p}=$ & 0,000 & \\
\hline \multicolumn{3}{|c|}{ Do you consider if a product is environmentally friendly when buying it? } \\
\hline Yes & 3401 & $109,0 \pm 17,6$ \\
\hline No & 1484 & $99,1 \pm 16,2$ \\
\hline$t=$ & 7,921 & \\
\hline $\mathrm{p}=$ & 0,000 & \\
\hline \multicolumn{3}{|c|}{ Were you interested in plants when you were a child? } \\
\hline Yes & 3674 & $106,6 \pm 17,8$ \\
\hline No & 1211 & $104,2 \pm 17,4$ \\
\hline $\mathrm{t}=$ & 4,120 & \\
\hline$p=$ & 0,000 & \\
\hline \multicolumn{3}{|c|}{ Did you take care of an animal when you were a child? } \\
\hline Yes & 3670 & $106,3 \pm 17,7$ \\
\hline No & 1215 & $105,1 \pm 18,0$ \\
\hline $\mathrm{t}=$ & 1,93 & \\
\hline$p=$ & 0,057 & \\
\hline \multicolumn{3}{|l|}{ Are you interested in plants? } \\
\hline Yes & 2806 & $107,6 \pm 17,9$ \\
\hline No & 2079 & $103,9 \pm 17,4$ \\
\hline$t=$ & 7,268 & \\
\hline $\mathrm{p}=$ & 0,000 & \\
\hline \multicolumn{3}{|l|}{ Do you take care of an animal? } \\
\hline Yes & 2647 & $107,1 \pm 18,1$ \\
\hline No & 2238 & $104,7 \pm 17,3$ \\
\hline $\mathrm{t}=$ & 4,533 & \\
\hline$p=$ & 0,000 & \\
\hline \multicolumn{3}{|c|}{ Do you talk to your family about environmental issues? } \\
\hline Yes & 2952 & $108,6 \pm 17,8$ \\
\hline No & 1933 & $102,0 \pm 17,0$ \\
\hline $\mathrm{t}=$ & 12,836 & \\
\hline$p=$ & 0,000 & \\
\hline \multicolumn{3}{|c|}{ Do you talk to your friends about environmental issues? } \\
\hline Yes & 3023 & $108,3 \pm 17,8$ \\
\hline No & 1862 & $102,3 \pm 17,1$ \\
\hline$t=$ & 11,468 & \\
\hline$p=$ & 0,000 & \\
\hline \multicolumn{3}{|c|}{ Do you follow the media content about environmental issues?* } \\
\hline Yes & 2640 & $108,6 \pm 18,5$ \\
\hline No & 2245 & $102,9 \pm 16,3$ \\
\hline $\mathrm{t}=$ & 11,574 & \\
\hline$p=$ & 0,000 & \\
\hline \multicolumn{3}{|c|}{ Do you post about environmental issues from your own social media accounts?* } \\
\hline Yes & 1936 & $109,7 \pm 19,2$ \\
\hline No & 2949 & $103,6 \pm 16,3$ \\
\hline $\mathrm{t}=$ & 11,419 & \\
\hline$p=$ & 0,000 & \\
\hline
\end{tabular}

${ }^{*} F$ and Sig values were checked in the analysis and "Equal variances not assumed" rows were examined since the significance values were less than 0.05 in all comparisons (their variances were not homogeneously distributed).

The T test results, in which the averages between the variables were compared, concluded that there were statistically significant differences $(p=0.000<0.05)$ between all 
demographic characteristics, except for taking care of an animal as a child, and the mean scores of environmental awareness. The results concluded that all basic characteristics and habits peculiar to the individual, especially gender, marital status and family type, were effective in the formation of environmental awareness.

Table 3. Frequency and Percentage Distribution of the

Environmental Awareness Levels of the Participants

\begin{tabular}{|c|c|c|c|c|c|c|}
\hline Satisfaction level & 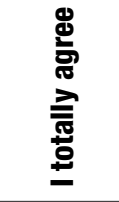 & 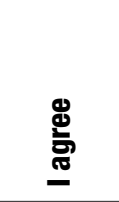 & 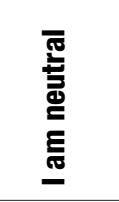 & 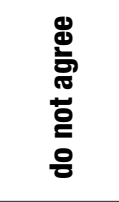 & 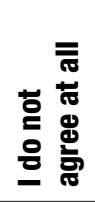 & 宓 \\
\hline 1.Environmental issues are important to me & $23.0 \%$ & $38.1 \%$ & $24.5 \%$ & $10.2 \%$ & $4.2 \%$ & $100.0 \%$ \\
\hline $\begin{array}{l}\text { 2.When buying a product, I consider how it will } \\
\text { affect the environment and other consumers. }\end{array}$ & $27.5 \%$ & $38.8 \%$ & $22.2 \%$ & $7.9 \%$ & $3.6 \%$ & $100.0 \%$ \\
\hline 3.I consider myself an environmentalist & $22.7 \%$ & $35.3 \%$ & $23.0 \%$ & $13.0 \%$ & $6.0 \%$ & $100.0 \%$ \\
\hline $\begin{array}{l}4 . I \text { believe that I can protect the environment } \\
\text { by buying environmentally friendly products. }\end{array}$ & $25.9 \%$ & $38.0 \%$ & $21.1 \%$ & $10.7 \%$ & $4.3 \%$ & $100.0 \%$ \\
\hline $\begin{array}{l}\text { 5.When buying products, I always act } \\
\text { with the awareness of buying products } \\
\text { that will pollute the environment less. }\end{array}$ & $30.7 \%$ & $39.6 \%$ & $17.5 \%$ & $8.1 \%$ & $4.1 \%$ & $100.0 \%$ \\
\hline $\begin{array}{l}\text { 6.When I have the chance to choose between two } \\
\text { equal products, I always prefer the product that is } \\
\text { less harmful to other people and the environment. }\end{array}$ & $24.2 \%$ & $36.8 \%$ & $24.2 \%$ & $10.8 \%$ & $4.0 \%$ & $100.0 \%$ \\
\hline $\begin{array}{l}7 . I \text { do not buy products that have the } \\
\text { potential to harm the environment. }\end{array}$ & $23.1 \%$ & $36.8 \%$ & $25.1 \%$ & $10.6 \%$ & $4.3 \%$ & $100.0 \%$ \\
\hline $\begin{array}{l}\text { 8.I do not buy products from companies } \\
\text { that do not respect the environment. }\end{array}$ & $22.3 \%$ & $40.1 \%$ & $24.8 \%$ & $9.3 \%$ & $3.5 \%$ & $100.0 \%$ \\
\hline $\begin{array}{l}\text { 9.I am very interested in organic, } \\
\text { ecological and natural products. }\end{array}$ & $19.9 \%$ & $39.5 \%$ & $26.5 \%$ & $10.6 \%$ & $3.4 \%$ & $100.0 \%$ \\
\hline $\begin{array}{l}10 . I \text { try to use electrical appliances when } \\
\text { the electricity consumption is low. }\end{array}$ & $30.3 \%$ & $41.4 \%$ & $18.2 \%$ & $6.9 \%$ & $3.3 \%$ & $100.0 \%$ \\
\hline $\begin{array}{l}\text { 11.I make hard efforts to reduce the } \\
\text { amount of electricity I use. }\end{array}$ & $22.6 \%$ & $39.8 \%$ & $24.0 \%$ & $9.7 \%$ & $4.0 \%$ & $100.0 \%$ \\
\hline $\begin{array}{l}\text { 12.I choose the light bulbs in the house from the } \\
\text { low voltage bulb types that consume less energy. }\end{array}$ & $21.0 \%$ & $39.0 \%$ & $26.0 \%$ & $10.4 \%$ & $3.6 \%$ & $100.0 \%$ \\
\hline $\begin{array}{l}\text { 13. The household goods I buy consume } \\
\text { less electricity than other brands. }\end{array}$ & $26.1 \%$ & $40.5 \%$ & $20.4 \%$ & $8.9 \%$ & $4.1 \%$ & $100.0 \%$ \\
\hline $\begin{array}{l}14.1 \text { try to buy products that are packaged in } \\
\text { reusable containers whenever possible. }\end{array}$ & $30.8 \%$ & $42.0 \%$ & $17.8 \%$ & $6.3 \%$ & $3.1 \%$ & $100.0 \%$ \\
\hline $\begin{array}{l}\text { 15.I prefer to buy recyclable products } \\
\text { such as paper, plastic, glass. }\end{array}$ & $18.6 \%$ & $36.7 \%$ & $29.4 \%$ & $10.6 \%$ & $4.8 \%$ & $100.0 \%$ \\
\hline $\begin{array}{l}\text { 16. I attach great importance to environmental } \\
\text { friendliness when purchasing many } \\
\text { products such as cosmetics, household } \\
\text { items, food, cleaning products, etc. }\end{array}$ & $34.9 \%$ & $37.8 \%$ & $15.8 \%$ & $6.8 \%$ & $4.8 \%$ & $100.0 \%$ \\
\hline $\begin{array}{l}\text { 17. Buying products made from recycled paper } \\
\text { is important to help preserve the forests. }\end{array}$ & $28.1 \%$ & $45.6 \%$ & $18.3 \%$ & $5.0 \%$ & $3.0 \%$ & $100.0 \%$ \\
\hline $\begin{array}{l}\text { 18.I can understand whether the product } \\
\text { is environmentally friendly from the } \\
\text { signs and symbols on the product. }\end{array}$ & $39.0 \%$ & $37.9 \%$ & $15.1 \%$ & $4.5 \%$ & $3.5 \%$ & $100.0 \%$ \\
\hline $\begin{array}{l}\text { 19.I can understand whether they are } \\
\text { environmentally friendly products from the } \\
\text { information about the content of many products. }\end{array}$ & $22.5 \%$ & $35.0 \%$ & $24.5 \%$ & $11.8 \%$ & $6.3 \%$ & $100.0 \%$ \\
\hline
\end{tabular}




\begin{tabular}{|c|c|c|c|c|c|c|}
\hline Satisfaction level & 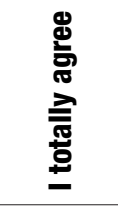 & 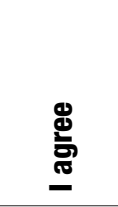 & 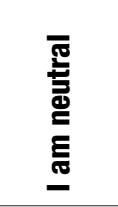 & 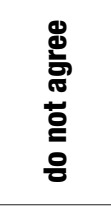 & 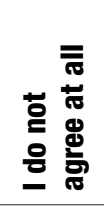 & 宓 \\
\hline $\begin{array}{l}20.1 \text { like evaluating things to be thrown away and } \\
\text { producing or creating other things from them. }\end{array}$ & $34.1 \%$ & $37.1 \%$ & $17.2 \%$ & $7.3 \%$ & $4.3 \%$ & $100.0 \%$ \\
\hline $\begin{array}{l}21 . I \text { am concerned about the harmful effects of } \\
\text { environmental pollution on me and my family }\end{array}$ & $50.3 \%$ & $32.3 \%$ & $11.1 \%$ & $3.2 \%$ & $3.1 \%$ & $100.0 \%$ \\
\hline $\begin{array}{l}22 . I \text { try to persuade my family members } \\
\text { and friends not to buy products } \\
\text { that harm the environment. }\end{array}$ & $18.6 \%$ & $36.7 \%$ & $24.9 \%$ & $10.6 \%$ & $9.2 \%$ & $100.0 \%$ \\
\hline $\begin{array}{l}\text { 23.I do not believe that the people in our country } \\
\text { are doing enough to protect the environment. }\end{array}$ & $34.9 \%$ & $37.8 \%$ & $15.2 \%$ & $6.8 \%$ & $5.4 \%$ & $100.0 \%$ \\
\hline $\begin{array}{l}\text { 24. Behaviours of consumers who buy the products } \\
\text { of socially responsible companies can have a } \\
\text { positive impact on environmental awareness. }\end{array}$ & $28.1 \%$ & $45.6 \%$ & $17.8 \%$ & $5.0 \%$ & $3.5 \%$ & $100.0 \%$ \\
\hline $\begin{array}{l}\text { 25.Our country faces a serious } \\
\text { solid waste problem. }\end{array}$ & $39.0 \%$ & $37.9 \%$ & $14.5 \%$ & $4.5 \%$ & $4.1 \%$ & $100.0 \%$ \\
\hline $\begin{array}{l}\text { 26.All warnings about the environmental } \\
\text { pollution are made by the media. }\end{array}$ & $22.5 \%$ & $35.0 \%$ & $24.0 \%$ & $11.8 \%$ & $6.8 \%$ & $100.0 \%$ \\
\hline $\begin{array}{l}\text { 27.Despite all warnings, we do not do } \\
\text { anything to protect the environment. }\end{array}$ & $34.1 \%$ & $37.1 \%$ & $16.8 \%$ & $7.3 \%$ & $4.6 \%$ & $100.0 \%$ \\
\hline $\begin{array}{l}\text { 28.Companies should encourage consumers to } \\
\text { collect solid waste (brochures, various gifts, etc.). }\end{array}$ & $50.3 \%$ & $32.3 \%$ & $10.8 \%$ & $3.2 \%$ & $3.4 \%$ & $100.0 \%$ \\
\hline
\end{tabular}

The level of participation in the statements in the scale used in the study is generally high. It is seen that the participants of the survey have the awareness that their individual behaviors and attitudes play an important role in the protection of the environment. At the point of purchasing the product, sustainable communication efforts will contribute to increasing this level of awareness. Because the results of the research show that people's awareness of nature and environmental protection is high.

\section{Conclusion}

Although this study generally gave statements on environmental awareness and sensitivity, the main purpose of the study was to determine the participants' levels awareness on household waste. The literature section included studies conducted in Turkey and in the world on the subject and described the low level of awareness on the subject. It is evident that waste rates are increasing day by day in the world due to the low awareness. Humans, who try to meet their needs for food and drink, which are shown as the most basic needs in Maslow's hierarchy of needs (Maslow, 1943), always has a diet based on exploiting nature, and "since 1950, world food output has more than doubled" (Brown, 1981, p. 995)Human beings have always met their most basic nutritional needs from nature since the societies that were hunt gatherers for most of the 200,000 years they lived on Earth (Angelakis, Asano, Bahri, Jimenez, \& Tchobanoglous, 2018, p. 7). The world population was around 1 billion in 1800, and since then, it has increased 7-fold (Roser, Ritchie, \& Ortiz-Ospina, 2013), causing the human population to grow exponentially (Hooke, 2000, p. 843). To date, approximately 108 billion people have lived on our planet (Roser vd., 2013) and human population growth is the most important of all global problems (Kapitzka, 1996, p. 40). The fact that nutrition and nature are used for this purpose, which is the most basic need for survival, increases the importance of protection and recycling of household wastes. 
One of the important findings of this study is the data obtained on the way household wastes are used. The current study concluded that $48.4 \%$ of the participants stated that they would give the kitchen waste to stray animals while $31.5 \%$ of them stated that they would throw it away. This high rate, which is thrown away, that is, cannot be recycled, seriously harms the environment. Furthermore, the family type of people, that is the number of people in the houses they live in, is an important determinant in terms of the volume of kitchen waste. The results indicated that $75.8 \%$ of the participants lived with a nuclear family. Considering the case of Turkey, the study suggests that there is much to be done, at least at the point of recycling household waste. Therefore, this study has revealed that projects are needed to increase people's awareness and knowledge on the subject.

The study made a comparison to determine the sensitivity and attitudes of the participants regarding their childhood and adulthood. While the rate of those who had been interested in plants when they were children was $75.2 \%$, the rate of those who were interested during the survey period decreased to $57.4 \%$. Likewise, those who had been taking care of animals as children were $75.1 \%$, the rate decreased to $54.2 \%$ when they became adults. Increasing urban life might be the reason for these decreases because the study observed that participants mostly lived in urban areas at the metropolitan and city level. The urban population, which was 25\% in 1950, reached 77\% in 2012 (Sürmeli, 2017, p. 275)and has been steadily increasing (almost 77 million people live in urban areas and only 6 million people live in villages). This migration wave is likely to have increasingly dramatic effects on environmental degradation unless there is a reverse migration.

The current study concluded that response levels for environmental sensitivity of the participants indicated a positive attitude in general. Buying environmentally friendly products at least once (69.1\%), considering if a product is environmentally friendly while buying it (69.6\%), talking about environmental issues to families $(60.4 \%)$ and to friends (61.9\%) showed that participants had awareness of the subject. In addition, the rate of following related media content was high (54.0\%). The interesting result was that although they followed the related media content, their level of posting about the subject from their own social media accounts was low (39.6\%). The fact that participants used social media for games and entertainment can be considered among the reasons for this. A growing body of literature has examined the motivation of using social media accounts in recent years. Whiting \& Williams (2013) conducted a study to reveal the reasons why people used social media. Their results showed that people used social media to pass their times, seek information, entertain themselves, relax, communicate with others, express their opinions, share information and surveil others. In this regard, stating that posting about the protection of the environment and nature is widespread among people is hard for the case of Turkey.

This research reveals the effect of human behavior on nature and the environment. In the light of the data obtained within the scope of the research, it is possible to say the following;

- It is obvious that people are open to communication about environmental awareness.

- The use of mass media is very important in order to increase the level of awareness on the subject.

- Consumers, who currently tend to buy environmentally friendly products, should be supported with messages designed in this direction and should be encouraged more. 
- Sustainable communication activities should be used as an important incentive tool in raising awareness and protecting the natural environment.

As Karaca stated, everyone has a responsibility to leave a better society and a better world for future generations (Karaca,2018 s.403). All of us have to know that, given the fact that human life depends on the survival of ecological life; governments, media, and companies have begun to bring up sustainability to the agenda more than before (Aydın and Tufan, 2018, s.397). Because, environmental protection is important for sustainability. Reilly and Hynan stated, economic sustainability references an organization's contribution to the ongoing viability of the larger economic system and social sustainability considers the firm's impact on the local communities in which it operates, ranging from corporate philanthropy to providing safe working conditions (2014, s.748). So the people have channeled their growing concern for the environment through the demand for ecofriendly products (Suki, 2016, s.2894) and this trend is also supported by this study.

People have experienced unconscious consumption behaviors and the deprivation of natural resources they have consumed since the day they existed. As Vuorinen, Juuti, \& Katko (2007) state, "the availability of water in large quantities has been considered an essential part of a civilized way of life in different periods" (s. 49), therefore talking about a civilization without water is not possible. Therefore, the findings of the current study indicate that people need awareness on the subject more than ever. Although there are many studies on protecting nature, gaining environmental awareness and recycling habits, the researcher suggests that increasing their numbers as soon as possible and raising more sensitive people for the next century hold great importance.

\section{References}

Akil, M. A., Foziah, J., \& Ho, C. S. (2015). The effects of socio-economic influences on households recycling behaviour in Iskandar Malaysia. Procedia-Social and Behavioral Sciences, 202, 124-134.

Angelakis, A. N., Asano, T., Bahri, A., Jimenez, B. A., \& Tchobanoglous, G. (2018). Water reuse: From ancient to modern times and the future. Frontiers in Environmental Science, 6(26).

Aydın, Ö., \& Aykaç, N. (2016). Yaratıcı drama yöntemi ile verilen eğitimin okul öncesi öğrencilerinin çevre farkındalığına etkisi. Yaratıcı Drama Dergisi, 1(1).

Aydın, S., \& Tufan, F. (2018). Sürdürülebilirlik ve yeşil kavramları bağlamında y

kuşağının satın alma davranışları. Selçuk İletişim, 11(2), 397-420.

Brown, L. R. (1981). World population growth, soil erosion, and food security. Science, 995-1002.

Corral-Verdugo, V. (1997). Dual 'Realitıes'of conservation behavior: Self-reports vs observations of re-use and recyclıng behavior. Journal of environmental psychology, 17(2), 135-145.

Çabuk, S., Nakıboğlu, A. G. B., \& Keleş, C. (2008). Tüketicilerin yeşil ürün satın alma davranışlarının sosyo demografik değişkenler açısından incelenmesi. Çukurova Üniversitesi Sosyal Bilimler Enstitüsü Dergisi, 17(1), 85-102.

De Young, R. (1986). Some psychological aspects of recycling: The structure of conservation-satisfactions. Environment and behavior, 18(4), 435-449. 
De Young, R. (2019). Supporting Behavioural Entrepreneurs: Using the biodiversityhealth relationship to help citizens self-initiate sustainability behaviour. İçinde In Biodiversity and Health in the Face of Climate Change (ss. 295-313). Cham: Springer.

Dinç, E., \& Üztemur, S. S. (2016). Afiş çalışmalarıyla ortaokul öğrencilerinin çevre farkındalıkları ve sosyal katılım becerilerinin geliștirilmesi. Abant İzzet Baysal Üniversitesi Eğitim Fakültesi Dergisi, 16(USBES Özel Sayı II.).

Ebreo, A., \& Vining, J. (1994). Conservation-wise consumers: Recycling and household shopping as ecological behavior. Journal of Environmental Systems, 23(2).

Fidan, Z., \& Acar Şentürk, Z. (2016). Sosyal medyada iletişim ve kadınlar üzerine bir değerlendirme. INIF E-Dergi, 1(2).

Gosling, E., \& Williams, K. J. (2010). Connectedness to nature, place attachment and conservation behaviour: Testing connectedness theory among farmers. Journal of environmental psychology, 30(3), 298-304.

Gönüllü, M. T., Doğan, S., \& Çelik, Z. (2015). İlköğretim öğrencilerinin çevre için zararlı ambalaj atıkları hakkında farkındalığı (İstanbul Örneği). Millî Ĕgitim, (205).

Granzin, K. L., \& Olsen, J. E. (1991). Characterizing participants in activities protecting the environment: A focus on donating, recycling, and conservation behaviors. Journal of Public Policy \& Marketing, 10(2), 1-27.

Harman, G., \& Çelikler, D. (2016). Fen Bilgisi Öğretmen Adaylarının Geri Dönüşüm Kavramı Hakkındaki Farkındalıkları. Bolu Abant İzzet Baysal Üniversitesi Sosyal Bilimler Enstitüsü Dergisi, 16(1).

Hayta, A. B. (2009). Sürdürülebilir Tüketim Davranışının Kazanılmasında Tüketici Eğitiminin Rolü. Journal of Kirsehir Education Faculty, 10(3).

Hobikoğlu, E. H. (2013). Davranışsal Finans Çerçevesinde E-Atık Geri Dönüşüm Yatırım Risk Algılamasında Tüketici Tercih Ve Davranış Düzeyinin Sosyo-Ekonomik Analizi: İstanbul Örneği. Finansal Araştırmalar ve Çalışmalar Dergisi, 4(9), 55-70.

Hooke, R. L. (2000). On the history of humans as geomorphic agents. Geology, 28(9), 843846.

Jekria, N., \& Daud, S. (2016). Environmental concern and recycling behaviour. Procedia Economics and Finance, 35, 667-673.

Kapitzka, S. P. (1996). The phenomenological theory of world population growth. Physics-uspekhi, 39(1), 39-57.

Karaca, Ş. (2018). Yaşam tarzının sürdürülebilir tüketim davranışı üzerindeki etkisini

belirlemeye yönelik bir çalışma. İşletme Araştırmaları Dergisi, 10(3), 403-425.

Karaca, Ș. (2013). Tüketicilerin Yeșil Ürünlere İlişkin Tutumlarının İncelenmesine Yönelik Bir Araştırma. Ege Akademik Bakış, 13(1), 99-111.

Latif, S. A., Omar, M. S., Bidin, Y. H., \& Awang, Z. (2012). Environmental values as a predictor of recycling behaviour in urban areas: A comparative study. ProcediaSocial and Behavioral Sciences, 50, 989-996.

Maslow, A. H. (1943). A theory of human motivation. Psychological Review, 50(4), 370396. 
Öztekin, C., Teksöz, G., Pamuk, S., Sahin, E., \& Kilic, D. S. (2017). Gender perspective on the factors predicting recycling behavior: Implications from the theory of planned behavior. Waste management, 62.

Reilly, A. H., \& Hynan, K. A. (2014). Corporate communication, sustainability, and social media: It's not easy (really) being green. Business horizons, 57(6), 747-758.

Roser, M., Ritchie, H., \& Ortiz-Ospina, E. (2013). World Population Growth. Ocak 2021, 20 tarihinde Our World in Data: https://ourworldindata.org/world-populationgrowth?source=post_page-----d904819ea029------------------ adresinden alındı

Singhirunnusorn, W., Donlakorn, K., \& Kaewhanin, W. (2012). Contextual factors influencing household recycling behaviours: A case of waste bank project in Mahasarakham municipality. Procedia-Social and Behavioral Sciences, 36, 688-697.

Suki, N. M. (2016). Green product purchase intention: impact of green brands, attitude, and knowledge. British Food Journal.

Sürmeli, İ. (2017). Türkiye'de iç göçün değişim ve dönüşümü: Kentten kıra yöneliş. Gazi Universitesi Iktisadi ve Idari Bilimler Fakultesi Dergisi, (Özel Sayı), 275-286.

Taş Divrik, M., Karakaş, H., \& Divrik, B. (2018). Meslek Yüksekokulu Öğrencilerinin Plastik Atıklar ve Geri Dönüşüme Yönelik Tutumları. Selçuk Üniversitesi Sosyal Bilimler Meslek Yüksekokulu Dergisi, 21(2).

Tunç, A. Ö., Ömür, G. A., \& Düren, A. Z. (2012). Çevresel Farkındalık. İstanbul Üniversitesi Siyasal Bilgiler Fakültesi Dergisi, (47).

Vuorinen, H. S., Juuti, P. S., \& Katko, T. S. (2007). History of water and health from ancient civilizations to modern times. Water Science and Technology: Water Supply, 7(1), 49-57.

Vural, Z. B. A., \& Bat, M. (2010). Yeni Bir İletişim Ortamı Olarak Sosyal Medya: Ege Üniversitesi İletişim Fakültesine Yönelik Bir Araştırma. Journal of Yaşar University, $5(20)$.

Whiting, A., \& Williams, D. (2013). Why people use social media: A uses and gratifications approach. Qualitative Market Research: An International Journal.

Yılmaz, V., \& Doğan, M. (2016). Planlanmıș Davranış Teorisi Kullanılarak Önerilen Bir Yapısal Eşitlik Modeli ile Geri Dönüşüm Davranışlarının Araştırılması. Anadolu Üniversitesi Sosyal Bilimler Dergisi, 16(Özel Sayı), 191-206. 


\title{
Geri Dönüşüm Konusunda Sürdürülebilir İletişimin İnsan Davranışı Üzerindeki Rolü: Türkiye Örneği
}

\author{
Zekiye Tamer Gencer (Assoc. Prof. Dr.)
}

\section{Genişletilmiş Özet}

Modern dünyada teknoloji tabanlı endüstriyel toplumlarda yaşayan insanlar son derece sert biyofiziksel sınırları ve doğal ekosistemleri bozmanın olumsuz sonuçları ile karşı karşıya kalmaktadır. Bu gerçeklik, kesin biçimde yeni bir davranışsal bağlam yaratarak, bu toplumların vatandaşları, yeni kaynaklar aramak ve bu kaynakları kullanmak için yeni bir yol geliştirmek, sonlu ekosistemlerin bilincinde olarak doğayı koruma, israfı önleme ve geri dönüşüm uygulamalarını hayat geçirme gibi iyi işleyen yeni yaşam kalıplarının oluşturulmasına yönelmek zorundadır. Dünyanın geleceğine dair sigorta niteliği taşıyan bu geçiş kaçınılmazdır. Bu gerçeklik ve gerekli olan sosyal değişim süreci insanların psikolojik kapasiteleri (örneğin, sosyal, duygusal, bilişsel) açısından ciddi bir davranış değişikliğini zorunlu kılmaktadır. Bu nedenle, öncelik, duygusal istikrar ve kararlılık olmalıdır. Çevre yanlısı davranışların nasıl teşvik edildiği konusunda da yapılması gereken bir takım değişiklikler ile oluşan yeni müdahaleler, insanların davranışsal girişimci olma koşullarını yaratmalı ve bu davranıșın yaygınlaşmasını sağlayarak teşvik edici olmalıdır.

$\mathrm{Bu}$ çalışma, insanların en başta ev tipi gıda atıkları olmak üzere çevreye attıkları tüm çöp ve atıklarla ilgili farkındalık yaratarak doğayı koruma, bu atıkların geri dönüşüm sayesinde yeniden kazanıldığında ise israfı önleme gibi önemli konulara farkındalıklarının oluşmasını sağlayarak ilgili hususlarda davranış ve tutumlarının değiştirilmesini sağlayıcı bilinçlendirme ve yönlendirme çalışması hususunda önerilerde bulunmak amacını taşımaktadır. Sürdürülebilir doğal kaynaklar ve bunların korunması, koruyucu insan davranış kalıpları olmaksızın mümkün değildir. Kaynak israfının önüne geçilmesi ve geri dönüşüm fikrinin yaygınlaşması noktasında insan duyarlılığına ve iletişime duyulan ihtiyaç her geçen gün artmaktadır. Çevre sorunlarında yaşanan olumsuzluklar ve dünyanın kaynaklarının hızla tüketiliyor olması koruma davranışını ve bu anlamdaki davranış değişikliğini zorunlu kılmaktadır. Çünkü yaşadığımız dünyada tüm insanların gelecek hakkında daha iyi hikayeler duymaya ihtiyacı her geçen gün artmaktadır.

Bu çalışma geri dönüşüm ve kaynakların korunması hususunda seçilen ev tipi tüketime ve genel çevre duyarlılığına yönelik bir bilinç seviyesinin ölçülmesi amacını taşımaktadır. Öncelikle Türkiye evreninden seçilen örneklem grubu üzerinde, çevre bilincini ve çevreye duyarlı ürünleri kullanma eğilimlerini belirlemek amacıyla bir anket çalışması gerçekleştirilmiştir. Hazırlanan anket formunda, 2013 yılında Karaca tarafından yapılan bir çalışmada benzer bir amacı ölçmek için geliştirilmiş bir ölçek kullanılmıştır. Ayrıca katılımcıların yaş, eğitim, meslek gibi demografik özellikleri ve sosyal medya kullanım alışkanlıkları ile geri dönüşüm davranışları hakkında veriler elde edilecek şekilde sorular sorulmuştur. Basit tesadüfi örnekleme yöntemi ile seçilen gruba belirlenen anket formu uygulanmıştır, çünkü evren büyük olduğu ve tutum ölçümü yapılacağı için nitel bir yöntem yerine survey yöntem tercih edilmiştir. Yapılan araştırmalar sonucunda en sık kullanılan ölçek tespit edilmiş ve anket formunun demografik sorularının arkasından bu ölçek yardımıyla veriler elde edilmiştir. Kolayda örnekleme yöntemi kullanılmış, örnekleme girmenin temel kısıtı 18 yaş ve üzeri olmak şeklinde belirlenmiştir. Örneklemden toplanan 
veriler ile insanların geri dönüşüm konusundaki bilinç düzeyi ve davranış biçimleri SPSS programı kullanılarak ölçümlenmiştir.

Ankete katılanların demografik özelliklerine ilişkin frekans analizi yapılmıştır. Katılımcıların \%60,8 i kadın, \%39,2 si erkektir; \%48,3 ü evli ve \%51,7 si bekardır. Eğitim düzeyleri ise, \%22,7 ilk ve orta öğretim, \%36,4 lise ve \%40,9 üniversite şeklindedir. Katılımcların \%38,6 sı gelirinin giderinden az, \%46,5 gelirinin giderine denk ve \%14,9 $\mathrm{u}$ da gelirinin giderinden fazla olduğunu ifade etmiştir. Çevre bilincinin oluşmasında önemli faktörlerden biri olan en uzun süre yaşam sürdürülen yerlerin dağılımı; \%23,1 büyükșehir, \%36,6 șehir, \%40,3 ilçe/köy/kasaba iken, şu an yaşanılan yer ise \%20 ,8 büyükșehir, \%46,3 şehir ve \%32,8 ilçe/köy/kasaba şeklindedir. Ayrıca ev tipi geri dönüşümün planlanması açısından önemli bir değişken olduğu düşünülen aile tipi ise, \%75,8 çekirdek aile ve \%24,2 geniş ailedir. Aile tipine göre miktarı değișen mutfak atıklarını değerlendirme yolları ise, \%48,4 düzeyinde sokak hayvanları verme şeklindedir. Ancak \%31,5 düzeyinde büyük bir oran ise çöpe atıyorum cevabını vermiştir.

Çalışma kapsamında, katılımcıların çocukken ve yetişkin oldukları döneme ilişkin duyarlılık ve tutumlarının tespiti için bir karşılaştırma yapılmıştır. Çocukken bitkilerle ilgilenenlerin oranı \%75,2 iken şu an ilgilenenlerin oranı \%57,4 e düşmüștür. Aynı şekilde çocukken hayvanlarla ilgilenenler \%75,1 iken şimdiki oran \%54,2 ye düşmüştür. Burada çocukluk dönemi ile yetişkinlik dönemi arasında değişen bu oranın artan kent yaşamına bağlamak mümkündür. Çünkü çalışmada insanların çoğunlukla büyükşehir ve şehir düzeyinde kentsel alanda yaşadıkları gözlenmiştir. 1950'de yüzde 25'lik bir orana sahip olan kent nüfusu 2012'de yüzde 77'ye (Sürmeli, 2017, s. 275) ve 2020 de ise bunun epeyce üstüne çıkmıştır (neydeyse 77 milyon kentli ve yalnıza 6 milyon köy nüfusundan bahsedilmekte). Bu yaşanan göç dalgasının da tersine göç olmadığı sürece çevre tahribatında giderek artan dramatik etkilerinin olması muhtemeldir.

Türkiye örnekleminde yapılan bu çalışmaya göre, katılımcıların çevre duyarlılıklarına iliş̧kin yanıt düzeyleri genel olarak olumlu bir tutuma işaret etmektedir. Bugüne dek en az bir kez çevre dostu ürün alma $(\% 69,1)$, ürün satın alımlarında çevre dostu olmasına özen gösterme $(\% 69,6)$, evde $(\% 60,4)$ ve arkadaş çevresinde $(\% 61,9)$ konuya ilişkin sohbet etme eğilimleri konuya ilişkin farkındalıklarının olduğunu göstermektedir. Ayrıca konuya ilişkin medya içeriklerini takip $(\% 54,0)$ oranı da yüksektir. Burada ilgi çekici olan sonuç ise, medya içeriklerini takip etseler de kendi sosyal medya hesaplarından konuya iliş̧in paylaşım yapma $(\% 39,6)$ düzeylerinin düşük olmasıdır. Sosyal medya kullanım alışkanlıklarının genel olarak oyun ve eğlence şeklinde olması, bunun nedenleri arasında düșünülebilir. Sosyal medya hesaplarının özellikle son yıllarda kullanım motivasyonlarına ilişkin sayısız çalışma yapılmıştır. Örneğin 2013 yılında yapılan bir araştırmaya göre, insanlar sosyal etkileşim, bilgi arama, zaman geçirme, eğlence, rahatlama, iletişimsel fayda, kolay kullanım, fikir ifadesi, bilgi paylaşımı ve başkaları hakkında gözetim (Whiting \& Williams, 2013) başta olmak üzere genellikle boş zaman aktivitesi olarak kullanmaktadır. Bu bağlamda bu platformlarda çevre ve doğanın korunmasına ilişkin ciddi içerik paylaşımlarının insanlar tarafından yaygınlaştırıldığını söylemek Türkiye örneklemi açısından zordur.

Anahtar Kelimeler: Çevre Bilinci, Geri Dönüşüm, Ev Tipi Atık, Tüketici Eğilimleri. 
Bu makale intihal tespit yazılımlarıyla taranmıştır. Intihal tespit edilmemiştir.

This article has been scanned by plagiarism detection softwares. No plagiarism detected.

Bu çalışmada "Yükseköğretim Kurumları Bilimsel Araştırma ve Yayın Etiği Yönergesi" kapsamında uyulması belirtilen kurallara uyulmuştur.

In this study, the rules stated in the "Higher Education Institutions Scientific Research and Publication Ethics Directive" were followed.

Araşıırma tek bir yazar tarafından yürütülmüştür.

The research was conducted by a single author.

Çalışma kapsamında herhangi bir kurum veya kişi ile çıkar çatışması bulunmamaktadır.

There is no conflict of interest with any institution or person within the scope of the study.

\section{Etik Kurul İzni I Ethics Committee Permission}

Cumhuriyet Üniversitesi Bilimsel Araştırma ve Yayın Etiği Sosyal ve Beşeri Bilimler Etik Kurulu'nun 21.01.2021 tarihli 37 nolu kararı çerçevesinde çalışma etik açıdan bir sakınca içermemektedir.

Within the framework of the decision taken during the meeting by Social and Human Sciences Ethics Committee of Cumhuriyet University dated 21.01.2021 and numbered 37; the study does not contain any ethical issues. 